Doi: $\underline{\text { dx.doi.org/10.17921/2525-5320.2016.155-157 }}$

\title{
A REPRESENTAÇÃO LITERÁRIA DE JOSÉ DE ALENCAR EM LIBRAS
}

\author{
Rita de Cássia Gomes Matoso Borges* - CATUAí \\ Celso Leopoldo Pagnan* - UNOPAR
}

Palavras-chaves: Inclusão. Literatura. Etnotexto. LIBRAS. José de Alencar.

\section{INTRODUÇÃO}

O tema inclusão escolar ainda instiga diversos estudiosos a pesquisar sobre aprimoramento didático para um atendimento de qualidade e não apenas quantitativo à clientela específica.

As lutas do Povo Surdo e Comunidade Surda foram árduas até chegar ao reconhecimento da Língua. Novas raízes começaram a surgir, fundindo novos estudos, como os que estão direcionados ao estudo da Língua em seu desempenho, especificamente como foco de estudo na representação literária.

O foco da discussão é a análise do processo de inclusão: como a Literatura e a representação poética são transmitidas aos Surdos? A tradução para a Língua Brasileira de Sinais (LIBRAS) consegue expressar a riqueza de detalhes da obra literária arraigada de metáforas e conceitos abstratos? A etnotextualidade da LIBRAS segue os mesmos princípios de sua estrutura base?

O estudo terá como base a leitura de Iracema, de José de Alencar, contemplando edição traduzida para LIBRAS.

O objetivo geral é analisar a $(\mathrm{Re})$ significação literária no processo de tradução para a LIBRAS respeitando a oralidade poética da língua enquanto representação cultural e identidade de uma comunidade específica: Povo Surdo. Quanto aos específicos, queremos pesquisar a etnotextualidade oral, identidade e cultura do Povo Surdo; coletar possíveis literaturas traduzidas em Língua de Sinais.

\footnotetext{
*E-mail: ritadecassiaborges@hotmail.com

*E-mail: celso.pagnan@unopar.br
} 


\section{MATERIAL E MÉTODOS}

A pesquisa bibliográfica terá como base os autores: Pélen, Zumthor, Terra, Leite, literaturas específicas da Cultura Surda: Skliar, Karnopp, Pimenta, Strobel, Sander, Montanher, Fernandes, Arriens, Gladis, entre outros.

A LIBRAS é uma língua visual-espacial que inicialmente foi marginalizada por não seguir os padrões normativos aceitáveis pela sociedade majoritária (cultura oralauditiva/ Língua Portuguesa), será que as produções do Povo Surdo ainda continuam a serem marginalizadas? Qual a performance poética existente na LIBRAS? Existem diferentes identidades culturais "Surdas", essas identidades são difundidas ou continuam a serem reprimidas socialmente? No corpus da pesquisa, os objetos de estudos serão: a Literatura de José de Alencar, os Surdos, sua Língua, Cultura e identidades na performance da tradução.

\section{RESULTADO E DISCUSSÃO}

No Brasil, como assevera Pereira (2006), o primeiro professor surdo foi Eduardo Huet, que veio de Paris em 1855 atendendo a uma solicitação da família real. Depois, fundou-se a primeira escola para surdos no Rio de Janeiro, o Instituto Nacional de Educação de Surdos - INES.

No século XX, a surdez começa a ser desmistificada. Em 1996, LIBRAS foi oficialmente reconhecida como língua perante as comunidades surdas e ouvintes. Por determinação da Lei n. 9.394, passou a ser obrigatória em currículos.

Apesar de todos os benefícios conquistados pela comunidade surda, segundo Montanher (2008, p.4), a grande maioria das pessoas considera a Língua de Sinais apenas como sendo o uso de mímicas.

Tomamos Iracema como base de estudo e análise, comparando a versão tradicional e a traduzida para Libras, para identificarmos valores socioculturais, na etnotextualidade da LIBRAS.

\section{CONCLUSÃO}

Buscou-se com a pesquisa viabilizar um conhecimento ainda não estudado, expandir conhecimentos a respeito da LIBRAS a fim de que a Comunidade Surda possa ter acesso à riqueza literária. Ao estabelecermos estas relações etnotextuais, 
contrapomos culturas e aguçarmos o gosto de poder conhecer o que antes era desconhecido de parcela da população.

\section{REFERÊNCIAS}

ALENCAR, J. Iracema. São Paulo: FTD, 1992

ALENCAR, J. Iracema. Ceará. Material bilíngue Português/Libras em CD-ROM. Tradutores para a LIBRAS: Heloíse Gripp Diniz e Roberto Gomes de Lima. Petrópolis: Arara Azul, 2012

LEITE, M.C.S. Reinventando lendas. ANTUNES, W.; COSTA, H. Candimba. Adaptação livre de uma lenda do folclore mato-grossense. UNICEN

MONTANHER, H. Apostila de Pós-Graduação "Lato Sensu" Educação Especial: Educação Bilíngue para Surdos - Libras/Língua Portuguesa. LIBRAS IV, 2008. Instituto Paranaense de Educação

PEREIRA, I. Apostila de ensino Básico de Libras. APASI - Associação de Surdos de Ibiporã, 2006

PELEN, J.-N. Memória da literatura oral. A dinâmica discursiva da literatura oral: reflexões sobre a noção de etnotexto. PUC-SP, v.22, p.49-77, 2011

SKLIAR, C. (Org.) Atualidades da educação bilíngue para surdos. Mediação. 2009

ZUMTHOR, P. A letra e a voz: a literatura medieval. São Paulo: Cia. das Letras, 1993. 